\title{
The Development Of Online Tutorial Moodle To Increase The Effectiveness Of Lectures During Pandemic Covid-19
}

\section{Pengembangan Tutorial Online Moodle Untuk Meningkatkan Efektifitas Perkuliahan Di Masa Pandemik Covid-19}

\author{
Sukardi ${ }^{(1)}$ Ratna Pancawati $^{(2)}$ Galfri Siswandi ${ }^{(3)}$ \\ 1), 2) 3) Pendidikan Teknik Mesin, Fakultas Keguruan dan Ilmu Pendidikan Universitas Palangka Raya \\ Kampus UPR Tunjung Nyaho Jl. H. Timang, 73111A \\ e-mail: sukardioto@fkip.upr.ac.id
}

\begin{abstract}
Efforts can be done to increase the effectiveness of conventional learning process by making additional interaction extension outside classroom. In this regard, information technology can be utilized. The use of information technology which has same function as the conventional inside classroom learning provided in online learning. This research aims at testing the validity and practicality of Moodle online tutorial. The research uses development design (R\&D). The research results show that online tutorial Moodle is valid $(95,37 \%)$ and practical $(80,36 \%)$ hence can be used in the online class widely.
\end{abstract}

Keywords: online tutorial Moodle, online class, Covid-19

\begin{abstract}
ABSTRAK
Upaya yang dapat dilakukan untuk meningkatkan efektifitas proses pembelajaran konvensional adalah dengan membuat ekstensi interaksi tambahan di luar kelas. Dalam hal ini, teknologi informasi dapat dimanfaatkan. Pemanfaatan teknologi informasi yang memiliki fungsi sama seperti pembelajaran di ruang kelas konvensional tersedia dalam pembelajaran online (daring). Penelitian ini bertujuan untuk menguji kevalidan dan kepraktisan tutorial online Moodle. Penelitian ini menggunakan desain pengembangan (R\&D). Hasil penelitian menunjukkan tutorial online Moodle dinyatakan valid $(95,37 \%)$ dan praktis $(80,36 \%)$ sehingga dapat digunakan pada kelas daring secara lebih luas.
\end{abstract}

Kata Kunci : Tutorial Online Moodle, Daring, Covid-19

\section{PENDAHULUAN}

Saat ini (tahun 2020), kecenderungan pemanfaatan media pembelajaran online semakin meningkat dalam dunia pendidikan apalagi di masa pandemic Covid-19. Konsep pembelajaran online yang kemudian lebih dikenal dengan istilah pembelajaran Daring (dalam jaringan) metode interaksinya berbeda dengan pembelajaran tatap muka di kelas. Pada metode tatap muka, biasanya mahasiswa dan dosen bertemu muka secara langsung di suatu ruang kelas. Berbeda dengan pembelajaran daring dimana keduanya tidak perlu bertemu langsung dalam suatu ruang kelas nyata. Kecanggihan teknologi informasi dapat memfasilitasi pembelajaran selakyaknya metode tatap muka, meskipun mahasiswa dan dosen tidak bertemu secara langsung dalam suatu ruang kelas nyata.

Keuntungan daring diantaranya dalam hal percepatan akses konten pembelajaran. Daring menyediakan konten yang dibutuhkan untuk belajar, baik dalam bentuk teks, gambar, grafik, video, dan audio. Berdasarkan pengamatan dalam kuliah tatap muka, hampir semua mahasiswa memiliki laptop ataupun smartphone, sehingga peluang akses terhadap konten pembelajaran semakin mudah dengan daring, dan sangat memungkinkan bagi mahasiswa untuk saling berbagi konten pembelajaran melalui perangkat elektronik. Kondisi seperti ini membuat konten pembelajaran semakin lebih cepat didapatkan atau lebih cepat didistribusikan. Selain itu, fleksibilitas akses melalui daring juga menjadi salah satu keunggulan dari pembelajaran daring. Mahasiswa dapat dengan mudah mengakses konten pembelajaran dimana saja, kapan saja, tanpa dibatasi ruang dan waktu. Karena keuntungannya yang sangat terasa, munculah berbagai model pengembangan pembelajaran daring seperti sekarang ini.

Selain keuntungan yang dimiliki oleh pembelajaran daring, kendala yang sering ditemui di dalam dunia pendidikan, lebih khususnya di perguruan tinggi mengharuskan pelaku pendidikan (dosen) memanfaatkan daring dalam proses pembelajaran mereka. Misalnya permasalahan belum optimalnya pelaksanaan Satuan Kredit Semester (SKS) yang selama ini memang dinilai masih kurang maksimal dalam proses pembelajaran di perguruan tinggi. 
Besarnya SKS mata kuliah dimaknai sebagai waktu yang dibutuhkan oleh mahasiswa untuk dapat menguasai kompetensi yang dirumuskan dalam suatu mata kuliah. 1 SKS setara dengan 160 menit kegiatan belajar mahasiswa. Untuk matakuliah umum (nonpraktik) terdiri dari 50 menit tatap muka ( $\mathrm{Tm}), 50$ menit belajar terstruktur $(\mathrm{Bt})$, dan 60 menit belajar mandiri (Bm) (Dirjendikti, 2014). Permasalahan yang sering dijumpai saat ini adalah: (1) terkadang dosen hanya memberikan kegiatan Tm, atau (2) dosen telah memberikan kegiatan Tm dan juga memberikan kegiatan Bt namun tidak terkontrol dengan baik, atau (3) dosen telah memberikan kegiatan Tm dan kegiatan Bt dengan baik, namun mahasiswa tidak memanfaatkan kegiatan Bm. Menurut Endrotomo (2016), menyatakan bahwa kondisi perkuliahan sekarang ini memang masih banyak yang belum melaksanakan SKS secara optimal, ada yang hanya melaksanakan kuliah Tm dan ujian saja. Jika kondisinya demikian, maka beban studi yang dilakukan dalam kegiatan perkuliahan hanya $1 / 3$ dari jumlah SKS yang telah ditetapkan. Salah satu upaya yang mungkin dapat dilakukan untuk mengatasi masalah-masalah tersebut adalah dengan membuat ekstensi untuk berinteraksi di luar kelas. Dalam hal ini, kemajuan teknologi informasi dapat dimanfaatkan.

Pemanfaatan fungsi diskusi seperti layaknya di ruang kelas nyata tersedia melalui daring. Dalam perkembangannya, daring digunakan pada sebagian besar institusi pendidikan di Indonesia saat ini terlebih lagi di masa pandemic Covid-19, baik dalam bentuk daring penuh (full-online) maupun dalam bentuk blanded learning.

Penyelenggaraan daring membutuhkan Learning Management System atau sering dikenal dengan istilah
LMS yang berfungsi untuk mengatur tata laksana penyelenggaraan pembelajaran. Terdapat banyak jenis LMS, namun moodle merupakan salah satu jenis LMS yang sangat lengkap digunakan untuk kepentingan pembelajaran. Seperti yang telah baru-baru ini diimplementasikan Universitas Palangka Raya melalui laman http://e-learning.upr.ac.id. Meskipun demikian, pembelajaran daring di Universitas Palangka Raya ini masih perlu pengembangan yang lebih baik lagi, baik dari sisi manajemen, SOP, maupun tutorial pembalajaran.

Salah satu faktor penunjang keberhasilan pembelajaran daring adalah tersedianya buku tutorial pembelajaran yang mudah dipahami oleh pengguna. Sukardi dan Rozi (2019) menyebutkan bahwa pembelajaran daring tidak begitu menguntungkan. Diantara alasan mahasiswa ragu dalam memilih pembelajaran daring adalah karena tidak terjadi tatap muka di dalam kelas mereka. Karena tidak terjadi tatap muka secara nyata. Oleh sebab itu, peran tutorial sangat penting untuk menunjang keberhasilan pembelajaran daring.

Dengan adanya tutorial pembelajaran berbasis online moodle, diharapkan permasalahanpermasalahan tersebut dapat teratasi. Selain itu, pengembangan tutorial pembelajaran berbasis online moodle diharapkan dapat meningkatkan efektivitas perkuliahan di Universitas Palangka Raya. Karena begitu urgennya masalah ini, tujuan penelitian dirumuskan sebagai berikut: "mengembangkan tutorial pembelajaran online moodle untuk meningkatkan efektifitas perkuliahan di Universitas Palangka Raya". Kerangka kerja penelitian pengembangan digambarkan pada gambar 1 sebagai berikut.

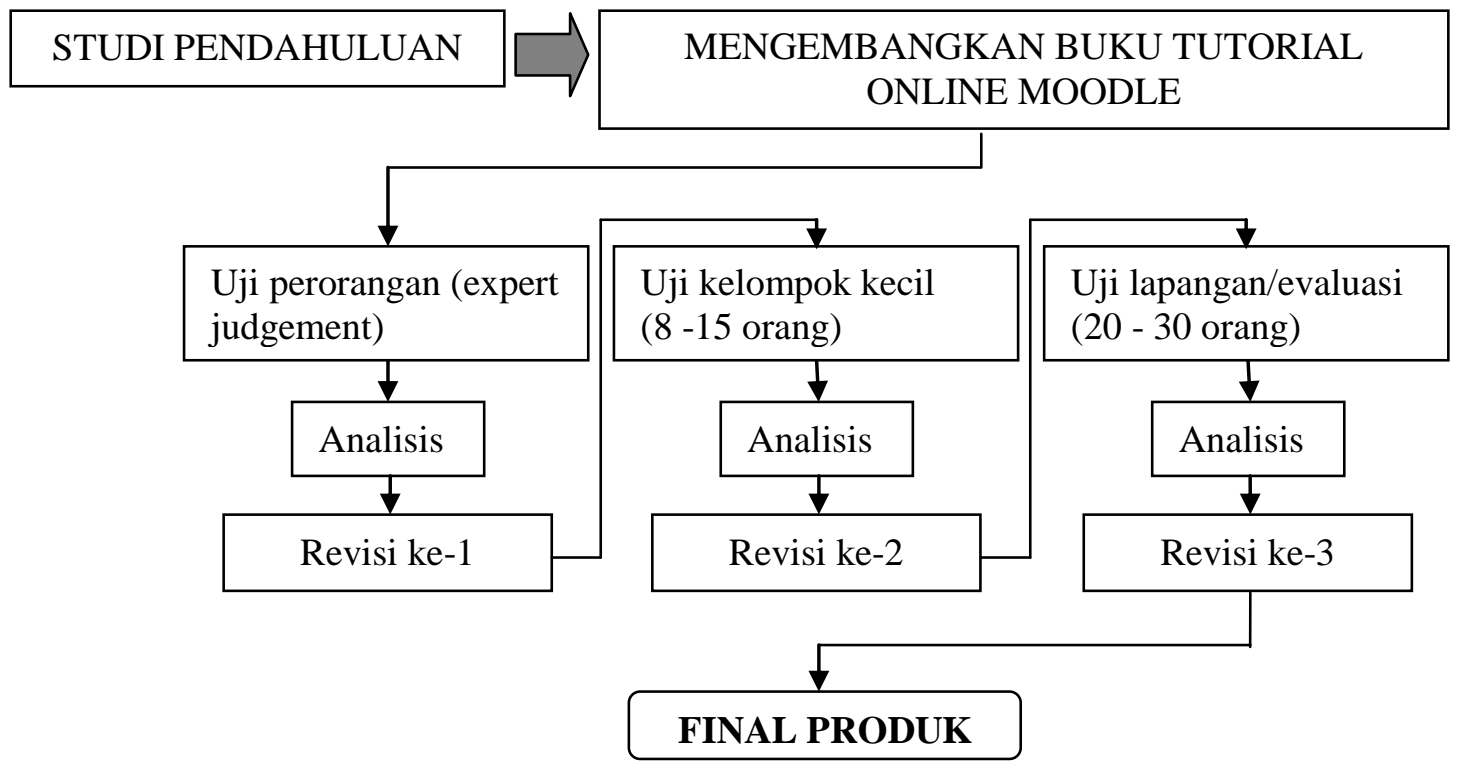

Gambar 1. Kerangka Kerja Penelitian Pengembangan 


\section{METODE}

Penelitian ini merupakan jenis Research \& Development (R\&D), bertujuan untuk menghasilkan produk tertentu, dan menguji keefektifan atau kwalitas produk tertentu (Gall dkk, 2003). Prosedur pengembangan dalam penelitian ini menggunakan 10 langkah yang dikembangkan oleh model pengembangan Dick, dkk (2015), yaitu: identify instructional goals, conduct instructional analysis, identify entry behaviours, write performance objectives, develop criterian reference tests, develop instructional strategy, develop and select instructional materials, develop and conduct formative evaluation, revise instructional, dan develop and conduct sumative evaluation.

Prosedur pengembangan meliputi tiga tahapan : studi pendahuluan, pengembangan produk, dan pengujian. Kegiatan dalam studi pendahuluan meliputi : studi/ pengumpulan data lapangan berkaitan dengan permasalahan yang akan dipecahkan. Sedangkan, kegiatan dalam tahap pengembangan meliputi : menetapkan tujuan untuk setiap tahap pengembangan, mengembangkan produk dan validasi ahli. Setelah validasi dilakukan, kegiatan selanjutnya adalah uji coba produk dimaksudkan untuk mengumpulkan data sebagai dasar untuk menetapkan tingkat kemenarikan dan efektifitas produk.

Desain R\&D melibatkan 3 orang dosen sebagai ahli (isi, bahasa dan media), 13 orang dosen, dan 14 orang mahasiswa sebagai objek uji coba. Untuk mengetahui kelebihan dan keterbatasan produk dilakukan dengan mengumpulkan data melalui angket dan dianalisis secara deskriptif. Sebelum digunakan instrument divalidasi dan hanya butir instrument yang valid saja digunakan.

Untuk dapat memberikan makna dan pengambilan keputusan digunakan ketetapan seperti pada tabel 1 berikut.

Tabel 1. Panduan Deskripsi Data

\begin{tabular}{|l|l|l|}
\hline $\begin{array}{l}\text { Tingkat } \\
\text { Pencapaian }\end{array}$ & Kualifikasi & Keputusan \\
\hline $90-100$ & Sangat baik & Tidak perlu revisi \\
\hline $75-89$ & Baik & Tidak perlu revisi \\
\hline $65-74$ & Cukup & Direvisi \\
\hline $55-64$ & Kurang & Direvisi \\
\hline$\geq 54$ & Sangat kurang & Direvisi \\
\hline
\end{tabular}

\section{HASIL DAN DISKUSI}

Untuk menjamin pembelajaran daring berjalan dengan baik, pengembangan tutorial menjadi hal yang penting. Kebingungan mahasiswa terhadap platform pembelajaran daring harus dihilangkan dengan cara menyiapkan tutorial yang mudah dipahami oleh mereka. Chi Ng (2007) telah melaporkan bahwa beberapa mahasiswa mengalami kesulitan awal dalam penggunaan system online, tetapi masalah dapat diselesaikan dengan dukungan tutor. Menurut Said dan Syarif (2016), bahwa tutorial sangat berguna dan efektif untuk meningkatkan proses pembelajaran online. Tutorial memiliki peran yg sangat penting karena dapat berfungsi sebagai panduan dalam proses pembelajaran. Dengan demikian, pengembangan tutorial harus dilakukan dengan sebaik mungkin, dan kwalitas tutorial menjadi salah satu penentu keberhasilan pembelajaran daring.

Untuk mendapatkan kwalitas tutorial (produk) yang baik perlu ada prosedur sistematis dan teruji. Uji validasi dan kepraktisan digunakan dalam penelitian ini untuk menentukan kwalitas tutorial. Uji validasi dilakukan oleh ahli atau pakar meliputi 3 aspek penilaian yaitu kelayakan isi, teknik penyajian dan bahasa. Sedangkan untuk uji kepraktisan dinilai berdasarkan persepsi dosen dan mahasiswa terhadap produk tutorial, meliputi indikator : teknik penyajian, bahasa, dan kemudahan dalam hal penggunaan. Hasil uji validasi produk disajikan dalam tabel 2 berikut.

Tabel 2. Uji Validasi

\begin{tabular}{lllll}
\hline Aspek & Skor & Skor Max & Persentase (\%) & Katagori \\
\hline Kelayakan isi & 35 & 36 & 97,22 & Valid \\
\hline Kelayakan teknik penyajian dan kegrafikaan & 137 & 144 & 95,14 & Valid \\
\hline Kelayakan bahasa & 90 & 96 & 93,75 & Valid \\
\hline Kesimpulan Akhir & & & $\mathbf{9 5 , 3 7}$ & Valid \\
\hline
\end{tabular}

Tabel 2 menunjukkan bahwa semua aspek penilaian uji validasi produk dalam kategori valid. Hasil validasi buku tutorial disajikan dalam tabel 2, menunjukkan bahwa persentase kevalidan terdiri: aspek kelayakan isi buku tutorial mencapai 97,22\% dalam kategori valid; aspek penyajian/ kegrafikaan buku tutorial sebesar 95,14\% dalam kategori valid; dan aspek kelayakan bahasa sebesar 93,75\% dalam kategori 
valid. Dengan demikian, secara kumulatif persetase hasil validasi buku tutorial adalah 95,37\%, diklasifikasikan dalam kategori valid.

Meskipun hasil validasi ahli tentang buku tutorial mendapat kesimpulan valid, namun beberapa saran dan masukan diberikan oleh ahli. Masukan-masukan tersebut digunakan untuk melakukan penyempurnaan. Masukan yang diberikan yaitu disajikan dalam tabel 3.

Tabel 3. Masukan Para Ahli

\begin{tabular}{lll}
\hline No. & Masukan Ahli & Tindakan Yang Dilakukan \\
\hline 1. & $\begin{array}{l}\text { Ditambahkan cara melihat hasil kuis, mendownload } \\
\text { hasil dari kuis/bagaimana memeriksa jawaban essay } \\
\text { dari menu kuis. }\end{array}$ & $\begin{array}{l}\text { Menambahkan cara melihat hasil kuis, } \\
\text { mendownload hasil dari kuis/bagaimana } \\
\text { memeriksa jawaban essay dari menu kuis. }\end{array}$ \\
\hline 2. & $\begin{array}{l}\text { Masih terdapat penulisan kata dalam bahasa asing } \\
\text { dan bahasa Indonesia yang belum tepat, terdapat } \\
\text { penulisan kata/istilah yang tidak konsisten. }\end{array}$ & Merevisi sesuai masukan yang diberikan. \\
\hline 3. & $\begin{array}{l}\text { Perlu ditambahkan capture tentang penggunaan LMS, } \\
\text { agar lebih memudahkan pengguna tingkat pemula. }\end{array}$ & $\begin{array}{l}\text { Menambahkan capture tentang } \\
\text { penggunaan LMS. }\end{array}$ \\
\hline
\end{tabular}

Untuk mengetahui kepraktisan produk dilakukan uji coba kelompok kecil. Terdiri dari 13 orang dosen diberikan buku tutorial dosen untuk digunakan di dalam kelas online mereka, kemudian mereka diminta untuk mengisi instrument penilaian terhadap buku tutorial yang telah digunakan. Demikian pula terhadap
14 orang mahasiswa, juga diberikan buku tutorial untuk digunakan di dalam kelas online mereka, lalu diminta untuk memberikan penilaian terhadap buku tutorial melalui angket. Hasil penilaian tersebut disajikan dalam tabel 4.

Tabel 4. Kepraktisan Produk

\begin{tabular}{lllll}
\hline Penilaian & Skor & Skor Max & Persentase (\%) & Katagori \\
\hline Kepraktisan buku tutorial Dosen & 424 & 468 & 90,60 & Sangat Praktis \\
\hline $\begin{array}{l}\text { Kepraktisan buku tutorial } \\
\text { Mahasiswa }\end{array}$ & 405 & 504 & 80,36 & Praktis \\
\hline
\end{tabular}

Berdasarkan tabel 4 menunjukkan bahwa kepraktisan buku tutorial dosen dalam kategori sangat praktis, dengan persentase $90,60 \%$. Kepraktisan buku tutorial mahasiswa dalam kategori praktis, dengan persentase $80,36 \%$. Dengan demikian, buku tutorial yang dikembangkan direkomendasikan untuk digunakan dalam kelas pembelajaran daring.

Berdasarkan hasil uji validasi dan kepraktisan produk, disimpulkan bahwa tutorial online Moodle yang telah dikembangkan telah memenuhi kwalitas yang baik. Dengan demikian, tutorial layak untuk digunakan dalam kelas yang lebih luas. Temuan ini mengindikasikan bahwa pengembangan yang sistematis dan teruji harus dilakukan sebelum sebuah tutorial (suatu metode) diimplementasikan dalam kelas. Sebuah tutorial dapat menjamin keterlaksanaan pembelajaran daring dengan baik jika memenuhi kwalitas yang baik, tidak asal dibuat. Pembelajaran daring mungkin akan gagal bukan karena mahasiswa tidak mampu menguasai materi tetapi karena kwalitas tutorial tidak dikembangkan dengan baik. Tutorial harus berperan secara maksimal dalam memandu mahasiswa saat proses pembelajaran daring.

Dalam beberapa studi, pembelajaran online (daring) murni dianggap tidak begitu menguntungkan. Tuncay dkk (2011) melakukan studi dengan tujuan untuk mengetahui perspektif peserta didik pada online. Hasil studi ini menyimpulkan bahwa sistem pembelajaran online cukup baik untuk pembelajaran, namun disisi lain tidak begitu menguntungkan. Hal ini dikarenakan pembelajaran online murni tidak memungkinkan terjadi tatap muka dalam kelas mereka sehingga seluruh kebutuhan pembelajaran tidak terakomodasi. Dengan demikian, peran tutorial menjadi sangat penting.

Tutorial merupakan sarana belajar-mengajar yang penting, dan sangat berguna untuk pengajaran dan pembelajaran. Tutorial membantu peserta didik meningkatkan kemampuan intelektual, komunikasi dan sosial peserta didik (Karve, 2006; Airinei dan Homocianu, 2010). Terlebih dalam pembelajaran daring, ketersediaan tutorial sangat dibutuhkan. Tutorial diperuntukkan untuk membantu kelancaran proses belajar madiri baik secara perorangan maupun kelompok.

Gagasan pengembangan tutorial dilandasi oleh tiga teori belajar yaitu; (1) teori mandiri atau SelfRegulated Learning (SRL). SRL menggambarkan proses dimana individu mengambil inisiatif dengan atau tanpa bantuan orang lain (instruktur) dalam mendiagnosis kebutuhan belajar mereka, mengidentifikasi sumber daya untuk belajar, melaksanakan strategi yang tepat 
dan mengevaluasi hasil belajar secara mendiri (Zimmerman, 2008); (2) teori scaffolding. Dalam teori scaffolding menjelaskan bahwa pengajaran yang efektif mengharuskan peran instruktur dalam memberi bimbingan atau tutorial (Wood, dkk, 1976); dan (3) teori Zone of Proximal Development (ZPD)., Dalam teori ZPD dijelaskan bagaimana individu memiliki tingkat perkembangan potensial, tingkat dimana dapat dicapai dengan bantuan orang lain, misalnya: instruktur, teman sebaya yang lebih maju, atau bentuk lainnya misalnya tutorial (Arend, 2008; Donato, 2005). Tutorial merupakan bentuk bantuan belajar dalam upaya memicu kemandirian dalam belajar dengan minimalisasi intervensi dari pihak lain seperti dosen atau instruktur. Banyak peserta didik gagal dalam belajarnya, disebabkan konsep yang dipelajarinya di dalam area ZPD mereka, namun tidak adanya bentuk bantuan yang segera diberikan. Dalam kondisi ini, mereka akan prustasi dan cenderung tidak dapat belajar dengan baik. Oleh karena itu, bantuan/scaffolding dalam bentuk tutorial sangat dibutuhkan untuk membantu peserta didik menjalani proses pembelajaran online.

\section{KESIMPULAN}

Hasil penelitian menemukan bukti empirik bahwa tutorial online Moodle yang dikembangkan telah memenuhi kwalitas yang baik ditinjau dari aspek validasi dan kepraktisan. Dengan demikian, tutorial layak digunakan dalam kelas yang lebih luas. Temuan ini mengindikasikan bahwa pengembangan yang sistematis dan teruji harus dilakukan sebelum sebuah tutorial atau suatu metode diimplementasikan dalam kelas.

Sebuah tutorial dapat menjamin keterlaksanaan pembelajaran daring dengan baik jika memenuhi kwalitas yang baik, tidak asal dibuat. Pembelajaran daring mungkin akan gagal bukan karena mahasiswa tidak mampu menguasai materi tetapi karena kwalitas tutorial tidak dikembangkan dengan baik. Tutorial harus berperan secara maksimal dalam memandu mahasiswa saat proses pembelajaran daring.

\section{DAFTAR PUSTAKA}

Al-Ani, W.T. (2013). Blended Learning Approach Using Moodle and Student's Achievement at Sultan Qaboos University in Oman. Journal of Education and Learning, 2(3), (pp 96-110), (online), (http://www.ccsenet.org/journal/ index.php/jel/article/viewFile/28509/17543), diakses 6 Juni 2020.

Airinei, D \& Homocianu, D. (2010). The Importance of Video Tutorials For Higher Education - The Example of Business Information Systems. Proceedings The 6th International Seminar Quality Management in Higher Education. (online),

(https://papers.ssrn.com/sol3/papers.cfm?abstract _id= 2381817), diakses 6 Juni 2020.

Alhothli, N.I. (2015). Investigating The Impact of Using Moodle As An E-Learning Tool For Students In An English Language Institute. Dissertations, University of Montana, (online), (http://scholarworks.umt. edu/cgi/viewcontent.cgi ?article $=5555 \&$ context $=$ etd ), diakses 6 Juni 2020.

Amandu, G.M., Muliira, J.K., \& Fronda, D.C. (2013). Using moodle e-learning platform to foster student self-directed learning: Experiences with utilization of the software in undergraduate nursing courses in a Middle Eastern university. Procedia - Social and Behavioral Sciences, (pp. 677 - 683), (online), (http://www.sciencedirect.com/science/article/pii/ S18770428 13033636), (online), diakses 6 Juni 2020.

Arends, R.L. (2008). Learning to Teach 7th. New York: McGraw Hill Companies

Creswell, J.W. (2012). Educational Research: Planning, Conducting, and Evaluating Quantitative and Qualitative Research Fourth Edition. Boston: Pearson.

Chanchary, F.H. \& Islam, S. (2009). Mobile Learning in Saudi Arabia Prospects And Challenges. Artikel. (online) (http://www.nauss.edu.sa/acit/PDFs/ f2535.pdf), diakses 30 Januari 2020.

Dewi, F. (2014). Edmodo: A Social Learning Platform for Blended Learning Class in Higher Education. Pedagogy and Technology Journal Vol XI/No 2. (online) (http://www.academia.edu/20300729/edmod o _asocial_learning platform_for_blended_learning_class_in_higher_ed ucation), diakses 25 Januari 2020.

Dick, W., Carey, L., \& Carey, J.O. (2015). The Systematic Design of Instruction. United States of America: Pearson.

Dirjendikti. (2014). Sistematika Permendikbud Standar Nasional Pendidikan Tinggi. (online), (http://pjm.ub.ac.id/wpcontent/uploads/2014/12/02-SN-DIKTI-dan-KPTDr.-Illah-Sailah-red.pdf), diakses 24 Januari 2020.

Donato, R. (2005). Collective Scaffolding in Second Language Learning. Article. (online), (http://lchc.ucsd.edu/mca/mail/xmcamail.201411.dir/pdfOvomcat_tx.pdf), diakses 6 Juni 2020.

Endrotomo. (2016). SKS: Pemikiran Perhitungan Jumlah Sks Program Pendidikan dan Besaran SKS Mata Kuliah. (online) (http://repo.unand. ac.id/3526/37/6.-sks.compressed.pdf), diakses 25 Januari 2020.

Eskandari, M. \& Soleimani, H. (2016). The Effect of Collaborative Discovery Learning Using MOODLE on the Learning of Conditional Sentences by Iranian 
EFL Learners. Theory and Practice in Language Studies, 6(1), (pp. 153-163), (online), (http://www.academypublication.com/ojs/ind ex.php/tpls/article/viewFile/

tpls0601153163/574), diakses 6 Juni 2020.

Gall, M. D., Gall, J.P., \& Borg, W.R. (2003). Educational Research: An Intro-duction (7th Edition). United States of America: Pearson Education, Inc.

Garcia, J. \& Somé, M. (2012). IT or not to be: The impact of Moodle in the education of developing countries. 1st Moodle ResearchConference, (pp 182 $-185)$. (online),

(https://upcommons.upc.edu/bitstream/

handle/2117/ 19366/paper-final-reviewed.pdf), diakses 6 Juni 2020.

Hew, K.F. \& Cheung, W.S. (2013). Review: Use of Web 2.0 technologies in K-12 and higher education: The search for evidence-based practice. Educational Research Review, (pp. 47-64). (online) (http://www.

sciencedirect.com/science/article/pii/S1747938X12 000620), diakses 24 Mei 2020.

Jumaat, N.F \& Tasir, Z. (2014). Instructional Scaffolding in Online Learning Environment: A Meta-Analysis. International Conference on Teaching and Learning in Computing and Engineering. (pp. 74 - 77), (online), explore.ieee.org/abstract/document/6821832/), diakses 6 Juni 2020.

Karve, A.V. (2006). Tutorials: Students' Viewpoint. Indian J Pharmacol. 38(3), (pp 198 - 99), (online), (http://www.ijp-online.com/article.asp?issn=02537613; year=2006; volume=38;issue=3; spage=198; epa ge=199;aulast=Karve), diakses 6 Juni 2020.

Tuncay, N.U.H \& Teker, N. (2011). Students evaluation of EDU 2.0: a case study. Procedia - Social and Behavioral Sciences (28), (pp.948 - 956). (online), (http://www.sciencedirect.com/science/article /pii/ S187704281102 6140), diakses 25 Januari 2020.

Wood, D., Bruner, J.S., \& Ross, G. (1976). The Role of Tutoring in Problem Solving. The Journal of Child Psychology and Psychiatry. (17), (pp 89 - 100), (online),

(http://onlinelibrary.wiley.com/doi/10.1111/ j.1469-7610.197 6.tb00381.x/full), diakses 6 Juni 2020.

Zimmerman, B.J. (2008). Investigating Self-Regulation and Motivation: His-torical Background, Methodological Developments, and Future Prospects. American Educational Research Journal, 45(1), (pp. $166-183), \quad$ (online), (http://journals.sagepub.com/doi/abs/10.3102/000 2831207312909), diakses 6 Juni 2020 